\title{
Who Cares About Mortgage Interest Deductibility?
}

\author{
Martin GeRVAIS
}

Economics Division, School of Social Sciences

University of Southampton, United Kingdom

Manish Pandey

Department of Economics

University of Winnipeg, Manitoba

Nous utilisons les données de la US Survey of Consumer Finances (Enquête sur les finances des consommateurs, aux États-Unis) afin d'évaluer l'impact sur les recettes fiscales d'une éventuelle annulation de la disposition fiscale qui permet de déduire des revenus imposables les intérêts hypothécaires aux ÉtatsUnis. Nous soutenons que l'élimination de cette disposition forcerait les ménages à remanier leur bilan, étant donné qu'ils devraient payer plus d'impôt sur les revenus d'intérêt. Nous montrons que le coût de cette disposition fiscale équivaut à une somme allant de $36 \%$ à $66 \%$ des évaluations que fait l'US Office of Management and Budget (l'équivalent américain du Conseil du Trésor canadien), selon les hypothèses que l'on fait au sujet des types d'actifs que les ménages utiliseraient pour réduire leur dette hypothécaire à la suite de l'annulation de la disposition. En outre, comme ce sont surtout les ménages les plus aisés qui pourraient alors remanier leur bilan, nous constatons que les effets distributifs de cette disposition fiscale sont beaucoup moins importants qu'on ne le croit habituellement. Même si cette étude concerne principalement l'impact de l'élimination de la disposition fiscale qui permet de déduire des revenus imposables les intérêts hypothécaires aux États-Unis, nos résultats permettent d'évaluer non seulement l'impact sur les recettes fiscales fédérales canadiennes mais aussi les effets redistributifs que pourraient avoir une éventuelle introduction de cette disposition fiscale au Canada.

Mots clés : déductibilité des intérêts hypothécaires, logement, fiscalité, redistribution

We use the US Survey of Consumer Finances to measure the change in federal tax liability that would result should mortgage interest no longer be deductible from taxable income. We argue that the elimination of this housing tax provision would lead households to reshuffle their balance sheet, thereby lowering the amount of interest income taxes collected. We find that the cost of this tax provision is between 36 and 66 percent of the estimates produced by the US Office of Management and Budget, depending on the types of assets one assumes would be used to lower mortgage debt following the removal of the provision. Furthermore, since mostly rich households would be in a position to reshuffle their balance sheet following such a change in tax policy, the distributional effects of this program are much smaller than conventionally believed. While the focus of this paper is on the elimination of mortage interest deductibility in the US, the results of this study shed some light on the impact and distributional consequences to expect should mortgage interest deductibility be introduced in Canada.

Keywords: mortgage interest deductibility, housing, taxation, redistribution 


\section{INTRODUCTION}

$\mathrm{T}$ he fact that owner-occupied housing capital receives a preferential tax treatment is well known. One such tax provision which receives a lot of attention, either because of its presence or absence from the tax code, is the deductibility of mortgage interest payments from taxable income. ${ }^{1}$ There are at least two reasons why mortgage interest deductibility (MID) draws such interest from academics and policy-makers alike. One is that this tax provision is perceived to be very costly for the government. The US Office of Management and Budget (OMB) estimates that mortgage interest deductibility will cost the government over $\$ 74$ billion of revenue losses in 2006, which represents around 7.5 percent of total individual income tax revenues as projected by the US Congressional Budget Office (CBO). Second, mortgage interest deductibility is widely perceived to benefit relatively wealthy households at the expense of less fortunate ones (e.g., see Maki 1996). Not surprisingly, the elimination of this tax provision periodically surfaces in policy debates in the US (for a recent example, see Bourassa and Grigsby 2000). In this paper, we argue that both the cost and re-distributional effects of mortgage interest deductibility are greatly overstated for the US. Although our study mainly focuses on the US, our results provide some insights for the debate in Canada where full or partial mortgage interest deductibility has been debated on several occasions over the years-the most recent example being the 2003 provincial election campaign in Ontario, during which the Progressive Conservative Party proposed to phase in deduction of mortgage payments from provincial income taxes. $^{2}$

The conventional belief that mortgage interest deductibility is regressive stems from the fact that home-ownership rates differ considerably across groups of different status (e.g., Poterba 1990). Using data from the 1998 US Survey of Consumer Finances (SCF), Figures 1 and 2 show that indeed the home-ownership rate (grey line) increases with income and, to a lesser extent, with wealth. These figures also show that the fraction of households with mortgage debt (black line) is higher for households with relatively high income or wealth, although this fraction levels off in both cases. A similar picture emerges from households who itemize deductions. ${ }^{3}$ Glaeser and Shapiro (2003) report that the fraction of itemizers in the top income decile (31 percent) is about eight times higher than the fraction of itemizers in the fifth decile of the distribution (4 percent). At first glance these figures lend some support to the conventional view that mortgage interest deductibility mainly benefits wealthy households, as they are more likely than poor households to be homeowners and have outstanding mortgage debt.

The central idea of this paper is that households would alter their balance sheet if mortgage interest were no longer deductible. ${ }^{4}$ Hence, knowledge of households' entire balance sheet is necessary to estimate the cost and re-distributional effects of this tax provision so that, in and of themselves, figures 1 and 2 paint an inaccurate picture of the cost and distributional effects of mortgage interest deductibility.

Along similar veins, Follain and Melamed (1998) use one of Follain and Dunsky's (1997) estimates for the elasticity of the demand for mortgage with respect to marginal tax rates, itself obtained through a reduced-form regression from a cross-section of households, and compute the cost of mortgage interest deductibility. They also argue that the figures published by the OMB overstate the amount of government revenue losses due to MID. ${ }^{5}$ Instead of relying on previously estimated elasticities, we use households' actual balance sheet from SCF data and speculate as to which assets households would use to reshuffle their balance sheet should mortgage interest no longer be deductible. The idea, of course, is that since the revenues generated by these assets are taxable under current US tax law, these revenues 


\section{FIGURE 2}

Home Ownership and Mortgage Incidence by Wealth

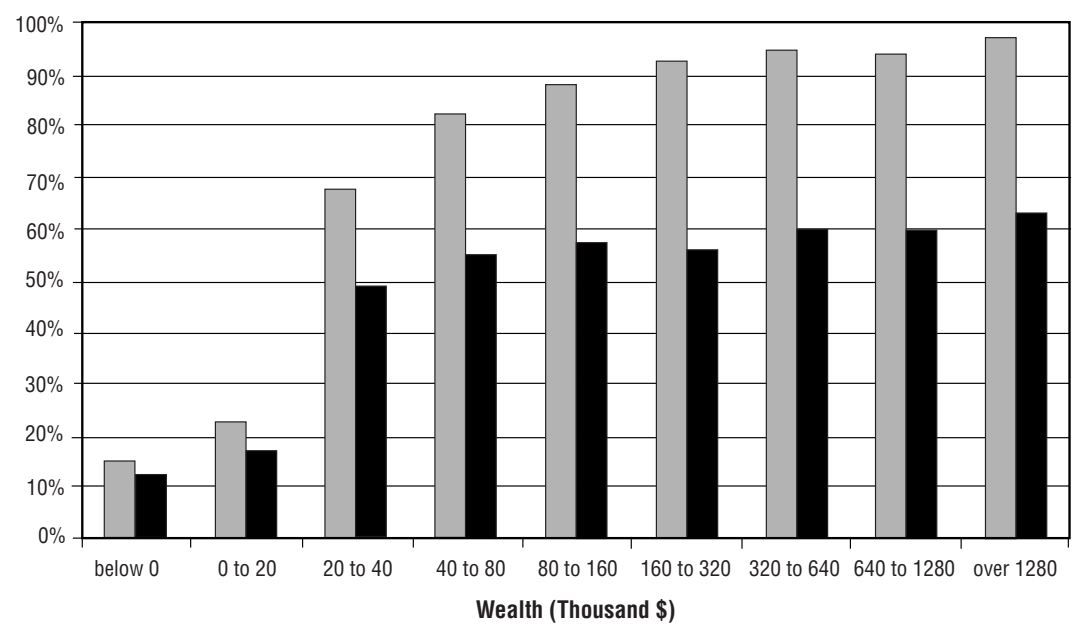

Ownership Rate

With Mortgage

Source: Authors' calculations using US SCF 1998 data.

FiguRE 1

Home Ownership and Mortgage Incidence by Income

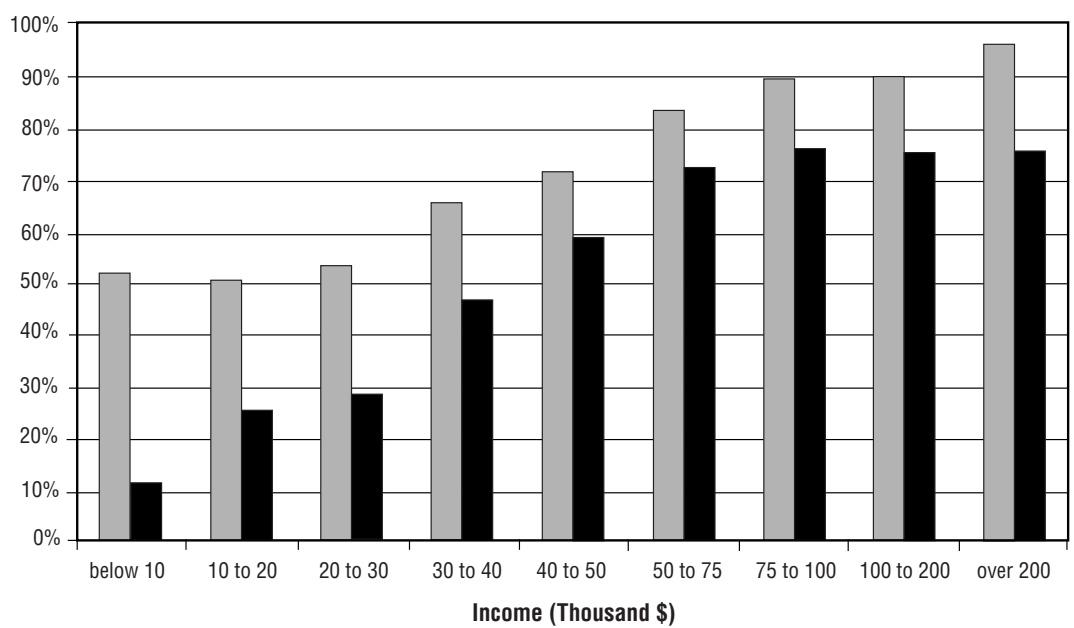

Ownership Rate

With Mortgage

Source: Authors' calculations using US SCF 1998 data. 
should be deducted from the cost of running the program. In addition to its simplicity, our approach is transparent in the sense that it follows directly from a standard specification of households' budget constraints. Moreover, an equivalent approach using flows rather than stocks can easily be implemented by the US Internal Revenue Service (IRS) from tax return data, thereby offering a simple way to estimate revenue losses due to MID.

To gain some confidence in the data available in the SCF, we first undertake the calculation of the cost of mortgage interest deductibility using the simple method used by the OMB, which is given by the difference between total federal tax liability with and without the tax provision. To do so, we compute the tax liability for each household in the SCF using the NBER TaxSim model (for fiscal year 1997) with and without the deduction. ${ }^{6}$ Our estimate of the cost of mortgage interest deductibility for 1997 is around $\$ 52$ billion, which is less than 2 percent lower than the $\$ 53$ billion figure reported by the OMB for fiscal year 1997. ${ }^{7}$ As a by-product, TaxSim reports an estimate of each household's marginal tax rate at the federal level. Using these marginal tax rates together with each household's reported mortgage interest payment in the SCF, we can obtain another measure of the cost of MID simply by adding up each household's cost. This simple measure, at $\$ 50$ billion, is sufficiently close to the IRS number to conclude that changes in marginal tax rates, which are ignored by this latter measure, are of second order.

A better measure of the cost of MID would take into account the fact that households would use some of their assets to pay off their mortgage debt should mortgage interest no longer be deductible. ${ }^{8}$ Since the government would lose the taxes collected on the interest generated by these assets, these taxes can be thought of as tax revenues made possible by mortgage interest deductibility. As such, this tax revenue should be deducted from the conventional (OMB) cost of this tax provision. We propose three such measures. Our first measure assumes that all non-pension wealth would be used to pay off mortgage debt if MID were eliminated. The cost of the program under this measure is under $\$ 20$ billion, which is less than 40 percent of the conventional measure. Under a more conservative measure, which assumes that only taxable financial assets other than liquid assets would be used to offset mortgage debt, the cost is still less than 66 percent of the conventional measure. Our preferred measure, which excludes all assets whose return may be either untaxed or tax-deferred, is around 60 percent of the OMB figure. In addition, it is interesting to note that the elasticity of mortgage demand estimated by Dunsky and Follain (2000) lies in the range of the elasticities implied by our proposed measures.

We also characterize who benefits from mortgage interest deductibility. As one would expect, our measures show significantly less of the benefits of this program going to wealthy households than the conventional measure: they are the households best equipped to pay off their mortgage once the tax advantage is removed. Contrary to the conventional measure, for which the benefits from MID increase with wealth, our preferred measure suggests that MID does not benefit richer households any more than the median wealth household. We also show that while the benefits of mortgage interest deductibility increase with income, they do not increase as fast as taxes paid at relatively high income levels. We thus find that mortgage interest deductibility makes the tax code less progressive at relatively low levels of income and more progressive at relatively high levels of income. We also show that mortgage interest deductibility is particularly important for new home buyers, a pattern that does not emerge with the conventional measure. Finally, we use Canadian data to gain further confidence in our measures of the cost and distributional effects of removing mortgage interest deductibility. We find that without MID, the US distribution of mortgage incidence by income and wealth and the asset holding patterns by age implied by our proposed measures are very similar to those in Canada. 
One aspect that we do not consider in this paper is that in addition to reshuffling their balance sheet, households could also change their housing tenure choice following the removal of mortgage interest deductibility. However, simulation results in Gervais (2002) imply that mortgage interest deductibility is relatively unimportant for the tenure decision: the home-ownership rate is only four percentage points higher in an economy with mortgage interest deductibility relative to an economy without the deduction. ${ }^{9}$ Consistent with our results, mortgage interest deductibility is relatively important for new homeowners, who purchase their first house at a younger age when mortgage interest payments are deductible. Similarly, Glaeser and Shapiro (2003) argue that mortgage interest deductibility is unlikely to have much of an impact on the home-ownership rate, and conclude that it is a poor instrument if the goal of the program is to increase the home-ownership rate. ${ }^{10}$

The rest of this paper is organized as follows. The next section discusses the reasons why measuring the cost of mortgage interest deductibility, or for that matter measuring any tax expenditure, is a difficult task. Our measures of the cost of mortgage interest deductibility are presented in the third sec- tion, and distributional effects are discussed in the following section. In the fifth section we present indirect evidence in favour of our measures by using data from Canada, where mortgage interest payments are not deductible. Concluding remarks are offered in the final section.

\section{Mortgage Interest Deductibility: A TAX Expenditure}

The US Congressional Budget Act of 1974 defines tax expenditures as "revenue losses attributable to provisions of the Federal tax laws which allow a special exclusion, exemption, or deduction from gross income or which provide a special credit, a preferential rate of tax, or a deferral of tax liability." The Budget Act also requires that a list of tax expenditures be included in the annual budget. As Table 1 shows, mortgage interest deductibility was the second-most important tax expenditure as reported by the US Office of Management and Budget for 2006.

Although the Budget Act requires disclosure of tax expenditures, it offers little guidance as to how to measure tax expenditures. Broadly speaking, tax

TABLE 1

Income Tax Expenditures, 2006

\begin{tabular}{clr}
\hline Rank & Provision & Cost (\$m) \\
\hline 1 & Exclusion of employer contributions for medical insurance premiums and medical care & 144,710 \\
2 & Deductibility of mortgage interest on owner-occupied homes & $\mathbf{7 4 , 7 9 0}$ \\
3 & Net exclusion of pension contributions and earnings: employer plans & 73,200 \\
4 & Net exclusion of pension contributions and earnings: 401(k) plans & 61,490 \\
5 & Capital gains (except agriculture, timber, iron ore, and coal) & 49,870
\end{tabular}

Source: US Office of Management and Budget (2005). 
expenditures are measured as the difference between the tax liability under present law and the tax liability that would result from a re-computation of the tax liability without benefit of the tax provision. There are obvious issues in measuring any tax expenditure. ${ }^{11}$ Two such issues are particularly important for mortgage interest deductibility. First, the concept of tax expenditure relies on the existence of a "normal" tax code, one that does not have such a provision. For instance, if we defined a normal tax system as one where the implicit revenue from owner-occupied housing (imputed rents) is taxed, then mortgage interest deductibility no longer constitutes a tax expenditure, as long as one accepts that interest on loans acquired to generate a revenue should be deductible against that revenue. Although this issue is of obvious importance, it is not the subject of this paper. ${ }^{12}$

A second issue is that strong assumptions on behaviour need to be made in order to measure tax expenditures. In particular, the numbers published by the OMB assume that individual behaviour remains unchanged once a tax provision is removed. In this paper, we argue that plausible changes in behaviour upon the elimination of mortgage interest deductibility paint a very different picture from that suggested by Table 1 .
Our argument is very simple since mortgage debt can be used, explicitly or implicitly, to purchase nonhousing assets which generate taxable income, households would reshuffle their balance sheet using these assets to pay off (at least part of) their mortgage debt upon the removal of mortgage interest deductibility. In other words, the income generated by these assets reduces the cost of allowing mortgage interest deductibility.

As an example, consider two households with balance sheets given in Table 2. In standard models, in which the borrowing and lending rates are equal, households are indifferent between either of these balance sheets as long as mortgage interest payments are deductible. However, these two balance sheets would lead to very different costs of MID using the OMB measure. This is because household $\mathrm{A}$ has an outstanding mortgage of $\$ 50,000$, which, at an interest rate of 10 percent and a tax rate of 20 percent appears to cost the government $\$ 1,000$ of tax revenues. Of course, this calculation omits the fact that this mortgage debt is implicitly used to hold $\$ 50,000$ worth of nonresidential assets generating $\$ 5,000$ of revenues which, if also taxed at 20 percent, completely offsets the mortgage deduction. Put differently, household A would sell off $\$ 50,000$ worth of non-

TABLE 2

Balance Sheets for Household A and Household B

\begin{tabular}{c|cc|c}
\hline \multicolumn{2}{c}{ Balance Sheet A } & \multicolumn{2}{c}{ Balance Sheet $B$} \\
\hline House & Mrtg debt & House & Mrtg debt \\
$h=200,000$ & $b=50,000$ & $h=200,000$ & $b=0$ \\
Non-res assets & & Non-res assets & \\
$a=100,000$ & & $a=50,000$ & \\
& Net worth & & Net worth \\
& $y=250,000$ & & $y=250,000$ \\
\hline
\end{tabular}

Source: Authors' compilation. 
residential assets if mortgage interest payments were no longer deductible.

In what follows we formalize this idea by computing the cost of mortgage interest deductibility, still in terms of government revenue losses, under different assumptions regarding the type of assets that individuals would use to lower their mortgage debt if the provision were eliminated.

\section{Measuring the Cost of Mortgage INTEREST DEDUCTIBILITY}

In this section we evaluate the amount of revenue the US government foregoes by allowing homeowners to deduct mortgage interest payments from taxable income. We compute four different measures of the revenue loss for the government. Our first measure, which we refer to as the conventional measure, is based on the calculations undertaken by the OMB to measure various tax expenditures. Accordingly, this measure assumes that households would not respond in any way following the removal of mortgage interest deductibility. Clearly, this measure constitutes an upper bound for the cost of MID, as one would expect households to alter their balance sheet to reduce their outstanding mortgage debt. Hence, we propose three measures that differ in their assumptions about how households would adjust their balance sheets to reduce their outstanding mortgage debt following the removal of mortgage interest deductibility. All three measures are computed under the assumption that households face the same exogenously given interest rate on borrowing and lending. ${ }^{13}$ For all measures, marginal income tax rates are household specific and are calculated using the TaxSim model. ${ }^{14}$ Of course, all calculations are for households that itemize their deduction, as the revenue loss to the government for non-itemizing households is zero. ${ }^{15}$ However, our measures do take into account the fact that some households may no longer choose to itemize their deductions once mortgage interest deductibility is removed.
To fix ideas, consider an age- $j$ household (indexed $k$ ) whose current net wealth, denoted $y_{j}^{k}$, is composed of housing asset $h_{j}^{k}$, of which $b_{j}^{k}<h_{j}^{k}$ is mortgaged, and net non-housing assets worth $a_{j}^{k}$, so that $y_{j}^{k}=a_{j}^{k}+h_{j}^{k}-b_{j}^{k}$. The budget constraint of this household is given by

$$
\begin{aligned}
c_{j}^{k}+p x_{j}^{k}+y_{j+1}^{k} & =w_{j}^{k}+(1+i) a_{j}^{k}+\left(1+i^{h}\right) h_{j}^{k} \\
& -(1+i) b_{j}^{k}-\tau_{j}^{k}\left(w_{j}^{k}+i a_{j}^{k}-i b_{j}^{k}\right)
\end{aligned}
$$

where $c_{j}^{k}$ is consumption; $p x_{j}^{k}$ is the value of housing services consumed; $w_{j}^{k}$ is wage income, $i$ is the common lending and borrowing interest rate, and $i^{h}$ is the implicit interest income on owner-occupied housing capital (imputed rents). ${ }^{16}$ The last term of this budget constraint corresponds to a tax code in which mortgage interest payments are fully deductible from taxable income-composed of interest and labour income-which is taxed at rate $\tau_{j}^{k}$.

Notice that both balance sheets in Table 2 would produce identical budget constraints according to equation (1). It is also interesting to note that since the US IRS necessarily collects data on both interest income ( $i a)$ and mortgage interest payments $(i b)$, it could easily compute the amount of mortgage interest that is offset by interest income. The approach we develop below, which is based on the balance sheet rather than the flow of income, is equivalent to this flow approach under the assumption of a common borrowing and lending interest rate. ${ }^{17}$ We use a balance sheet approach since assets and liabilities are better measured in SCF data than interest income.

\section{Conventional Measure}

The conventional measure of the revenue loss to the government is the difference between the total amount of taxes that would be collected without allowing for MID and total taxes collected with MID. 
This is indeed how the OMB arrives at the conclusion that government revenue loss due to MID was around $\$ 53.08$ billion in 1997. Using our sample from the SCF for 1998 (tax year 1997), we use TaxSim to compute total tax liabilities with and without MID. Doing so, our conventional measure of the revenue loss due to MID is $\$ 52.13$ billion, which is very close to the revenue loss reported by the OMB. ${ }^{18}$

Notice that if households' marginal tax rates were unaffected by this change in the tax code, then we could compute the conventional measure simply by adding up each household's deduction, times their marginal tax rate:

$$
C=\sum_{k} \tau^{k} \times(i \times b)^{k}
$$

where $(i \times b)^{k}$ is taken from the SCF and $\tau^{k}$ is TaxSim's estimate of household k's marginal federal tax rate. ${ }^{19}$ Doing so results in a cost of $\$ 50.03$ billion, which is very close to the $\$ 52.13$ billion figure we obtained above. We conclude that changes in marginal tax rates are of second order and assume for our three measures below that marginal tax rates remain constant following the removal of MID.

\section{Alternative Measures}

Our approach is based on households' balance sheet. Under full mortgage interest deductibility, the budget constraint (1) can be written as

$$
\begin{aligned}
c_{j}^{k}+p x_{j}^{k}+y_{j+1}^{k} & =\left(1-\tau_{j}^{k}\right) w_{j}^{k}+y_{j}^{k} \\
& +i^{h} h_{j}^{k}+\left(1-\tau_{j}^{k}\right) i\left(a_{j}^{k}-b_{j}^{k}\right) .
\end{aligned}
$$

The last term in (3) implies that households are indifferent between many different balance sheets: as long as the same interest rate applies to borrowing and savings, households only care about nonhousing assets net of mortgage debt, as opposed to the exact composition of their balance sheet. Fur- thermore, if we assume that revenues from all assets are taxed at the same rate, government revenues are also unaffected by the composition of assets and liabilities.

More precisely, the argument is that if household $k$ 's net worth is large enough for this household to own its house outright $\left(y^{k}>h^{k}\right.$ or equivalently if $\left.a^{k}>b^{k}\right)$, then the entire mortgage is implicitly used to finance other assets. Since these assets generate income $i a^{k}$ which is taxed at rate $\tau^{k}$, the OMB overstates the cost of MID by $\tau^{k} \times i \times b^{k}$, as this household's assets generate taxable revenues that exactly offset its mortgage deduction. Similarly, if a household's net worth is insufficient to own its house outright $\left(a^{k}<b^{k}\right)$, then the miscalculation consists of the revenues on non-housing assets held by the household, that is, $\tau^{k} \times i \times a^{k}$. The aggregate miscalculation, then, is given by

$$
\Delta=\sum_{\left\{k \mid a^{k} \geq b^{k}\right\}} \tau^{k} \times i \times b^{k}+\sum_{\left\{k \mid a^{k}<b^{k}\right\}} \tau^{k} \times i \times a^{k},
$$

and government revenue losses are given by

$$
C^{*}=\sum_{\left\{k \mid a^{k}<b^{k}\right\}} \tau^{k} \times i \times\left(b^{k}-a^{k}\right) .
$$

Ideally, one would like to know the exact amount of revenues generated by each component of households' balance sheet. Unfortunately, the SCF does not provide such information. ${ }^{20}$ Instead, we specify a set of assets which we assume generate interest income at a common interest rate $i$, while all other assets are assumed to generate tax-free revenues. Only the former assets are included when we compute our measure of government revenue losses $C^{*}$ in (5), as only these assets would be used to lower mortgage debt if the deduction were eliminated. ${ }^{21}$ Our three measures below differ as to which assets fall into each category. To implement these measures, we set the interest rate such that government revenue losses in equation (2) under that common 
interest rate are equal to the conventional measure of the revenue loss computed above ( $\$ 50.03$ billion). The interest rate works out to be 7.29 percent.

Table 3 shows the components of the balance sheet that we construct for each household in SCF, along with the elements of our most comprehensive measure of interest-bearing assets. For this inclusive measure, we define interest-bearing asset $\left(a^{k}\right)$ as all (net) non-housing assets other than vehicles and assets accumulated for retirement purposes (such as $401 \mathrm{k}$ and thrift accounts). ${ }^{22}$ We think of this measure as a lower bound on the revenue loss to the government from providing taxpayers with mortgage interest deductibility as it assumes that the vast majority of assets acquired through mortgage debt generate taxable income and would be used to lower mortgage debt if MID were eliminated.

Our second definition of interest-bearing assets only includes non-liquid, taxable financial assets (excluding financial assets accumulated for retirement) plus net non-residential real estate assets and other (net) non-financial assets (see Table 3). This measure, our preferred measure, excludes assets whose returns may be untaxed in the short run or tax-deferred. We chose to exclude business assets as we believe that, although households may borrow against their house to finance their business interests, it is unlikely that they would sell their business interests to reduce their outstanding mortgage in the absence of mortgage interest deductibility. Similarly,

\section{TABLE 3}

Balance Sheet: Preferred and Inclusive Measures

\begin{tabular}{|c|c|c|c|}
\hline & Assets & & Liabilities \\
\hline & Financial Assets & & Mortgage Debt \\
\hline$\checkmark$ & Liquid assets & & Principal residence \\
\hline$\star$ & $\operatorname{CDS}$ & & Second residence \\
\hline$\star$ & Taxable NMMF & & \\
\hline$\hat{\jmath}$ & Tax-exempt NMMF & & \\
\hline$\star$ & Stocks & & \\
\hline$\star$ & Taxable bonds & & \\
\hline \multirow[t]{2}{*}{$\checkmark$} & Tax-exempt bonds & & \\
\hline & $\begin{array}{l}\text { Retirement assets (including } \\
\text { tax-deferred equity and bonds) }\end{array}$ & & \\
\hline \multirow[t]{4}{*}{$\star$} & Other financial assets & & \\
\hline & Non-Financial Assets & & Other Debt \\
\hline & Vehicles & $\checkmark$ & Other lines of credit \\
\hline & House(s) & $\checkmark$ & Loans \\
\hline$\checkmark$ & Business (net worth) & $\checkmark$ & Other debt \\
\hline$\checkmark$ & Other residential assets & & \\
\hline$\star$ & Net non-residential equity & & \\
\hline$\star$ & Other (net) non-financial assets & & Net worth \\
\hline
\end{tabular}

Note: $\checkmark$ indicates assets included for the preferred measure while in addition to $\star$ the inclusive measure includes assets (minus liabilities) indicated by $\checkmark$.

Source: Authors' compilation. 
we excluded liquid assets as these assets may serve purposes other than generating interest income.

Our third and last definition of interest-bearing assets only consists of non-liquid, taxable financial assets. Relative to our preferred measure, this measure removes non-financial assets from the set of assets with taxable revenues. We consider this to be a fairly conservative measure of interest-bearing assets that could be used to lower mortgage debt, and so will its corresponding revenue loss measure.

Table 4 reports our estimates of government revenue losses from mortgage interest deductibility for each measure. Depending on the definition of interestbearing assets, the revenue loss for the government is between $\$ 18.15$ billion and $\$ 32.91$ billion, that is, between 36 percent and 66 percent of the conventionally measured revenue loss. Even relative to our conservative measure, the conventional measure greatly overstates the revenue loss from this program. Table 4 also presents the percentage increase in tax revenues the government should expect following the elimination of mortgage interest deductibility. According to our preferred measure, federal tax revenues would increase by about 3.3 percent which, although substantial, is more than two percentage points below the conventional estimate.

The last two rows of Table 4 report the loan-tovalue (LTV) ratios and mortgage debt-to-GDP ratios that obtain following the removal of mortgage interest deductibility under the four measures. The actual LTV ratio for 1997, which obtains under the conventional measure, was just above 40 percent. Under our preferred measure, the LTV ratio is around 30 percent. It is interesting to note that the LTV ratio in Canada, where mortgage interest is not deductible, was around 27.5 percent in $1999 .{ }^{23}$ Similarly, mortgage debt-to-GDP in Canada in 1999 was between 30.7 percent (for mortgage debt on principal residences) and 35.5 percent (for total mortgage debt), which is close to the 30.45 percent we obtain under our preferred measure. We will present more evidence from Canadian data in the fifth section.

\section{Implied Elasticity of Mortgage Demand}

Each measure we propose in the previous section implicitly defines a price elasticity of the demand for mortgage debt. First, removing mortgage interest deductibility implies an increase in the price of mortgage debt for a household from $i \times(1-\tau)$ to $i$. Second, each of our three measures implies a change in mortgage debt for each household following the removal of the tax provision. We can thus use the change in mortgage demand and the change in its price to estimate the elasticity of mortgage demand implied by each of our measures using the following regression:

$$
\begin{aligned}
\ln \left(M_{a d j}^{k}\right)-\ln \left(M^{k}\right)= & \alpha+\beta(\ln (i) \\
& \left.-\ln \left(i \times\left(1-\tau^{k}\right)\right)\right)+\varepsilon^{k},
\end{aligned}
$$

TABLE 4

Revenue Loss from Mortgage Interest Deductibility

\begin{tabular}{lrrrr}
\hline & Conventional & Conservative & Preferred & Inclusive \\
\hline Cost of MID (\$ billion) & 50.03 & 32.91 & 29.18 & 18.15 \\
Relative federal tax (\%) & 5.71 & 3.76 & 3.33 & 2.07 \\
Relative total tax (\%) & 4.82 & 3.71 & 2.81 & 1.75 \\
Loan-to-value ratio (\%) & 40.28 & 31.84 & 29.94 & 21.69 \\
Mortgage debt-to-GDP ratio (\%) & 46.81 & 33.32 & 30.45 & 20.51 \\
\hline
\end{tabular}

Source: Authors' compilation. 
where for a household $k, M$ is the original mortgage outstanding, $M_{a d j}$ is the mortgage outstanding for one of the three measures after the removal of mortgage interest deductibility and $\varepsilon$ is an i.i.d. error term. The left-hand side of the regression equation is the change in the logarithm of mortgage outstanding while the right-hand side is the change in the logarithm of the price of mortgage debt. The estimate of $\beta$ from the regression measures the elasticity of mortgage demand with respect to its price.

The implied price elasticities of mortgage demand are $-0.54,-0.70$ and -1.42 for the conservative, preferred, and inclusive measures, respectively. Since the inclusive measure allows for more assets to be used to offset mortgage debt than the conservative measure, the price elasticity implied by the former is naturally higher than for the latter. It is interesting to note that Dunsky and Follain (2000), using the 1986 US tax reform, estimate the elasticity of mortgage demand to be about -1.13 , which is in the range of the elasticities implied by our measures of assets that would be used to lower mortgage debt following the removal of mortgage interest deductibility.

\section{Distributional EFFECTS OF MID}

In this section we study how government revenue losses from mortgage interest deductibility are distributed. We show that although the benefits from MID are increasing in income for our preferred measure, they do not increase as fast as tax liabilities. Accordingly, we argue that mortgage interest deductibility does not decrease the degree of progressivity of the tax code, contradicting the conventional wisdom that this program is highly regressive.

Figure 3 depicts the benefits from mortgage interest deductibility across the income (AGI) distribution for our four measures. ${ }^{24}$ While all

FIGURE 3

Distribution of Benefits of MID by Income

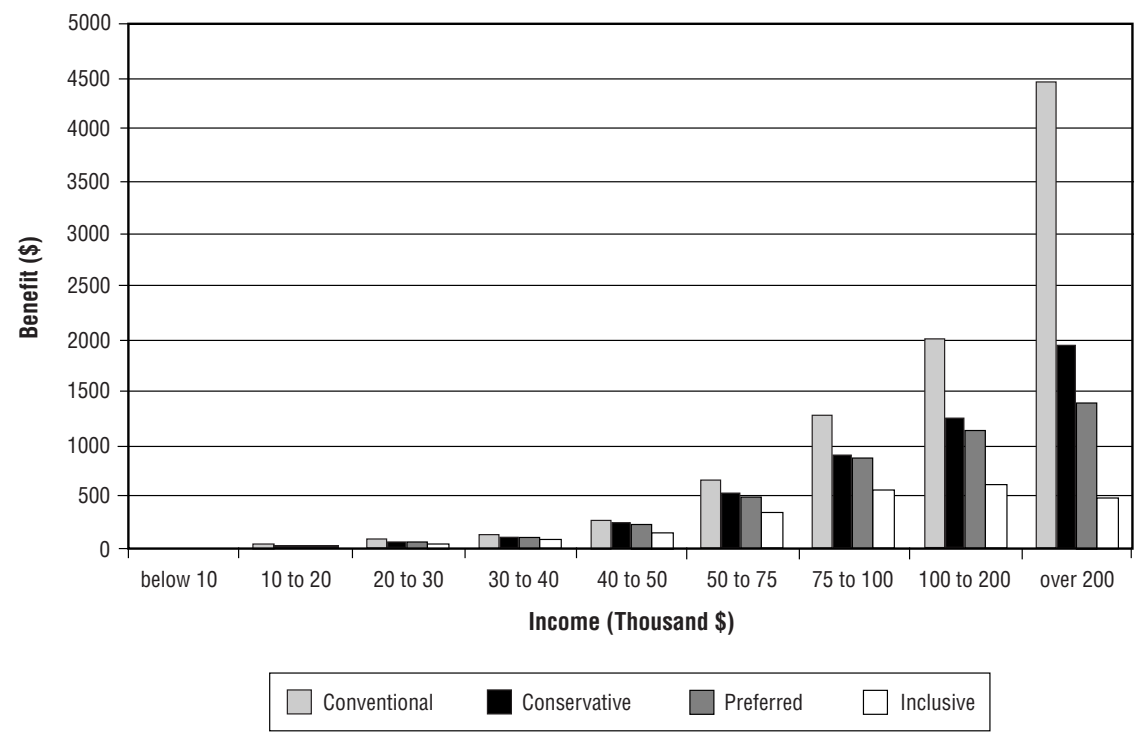

Source: Authors' calculations using US SCF 1998 data. 
measures of the benefits increase with income, the increase is much less pronounced according to our preferred measure than the conventional one. The average benefit for households with income above $\$ 200,000$ is more than 30 times the average benefit for households with income between $\$ 30,000$ and $\$ 40,000$ using the conventional measure. For our preferred and inclusive measures respectively, this number is 14 and 6 times the average benefit for households with income between $\$ 30,000$ and $\$ 40,000$.

An interesting and recurring question in the literature is whether mortgage interest deductibility increases or decreases the degree of progressivity of the US tax code. Figure 4 plots the benefits of MID relative to taxes paid across the income distribution. ${ }^{25}$ This figure shows that for all but the conventional measure, while the benefits from MID increase with income, they do not increase as fast as federal taxes paid for income above $\$ 50,000$. In other words, mortgage interest deductibility makes the tax code less progressive at relatively low levels of income, and more progressive for relatively high levels of income. It is interesting to note that even for the conventional measure; mortgage interest deductibility does not make the tax system less progressive at all income levels.

One would also expect new homeowners to care more about mortgage interest deductibility than households who have long been homeowners. Figure 5 plots the home-ownership rate by age, as well as the fraction of households with mortgage debt. The homeownership rate increases rapidly until age 40 , after which it remains stable around 75 to 80 percent. While the fraction of households with positive mortgage debt

\section{FIGURE 4}

Distribution of Benefits of MID Relative to Federal Taxes Paid

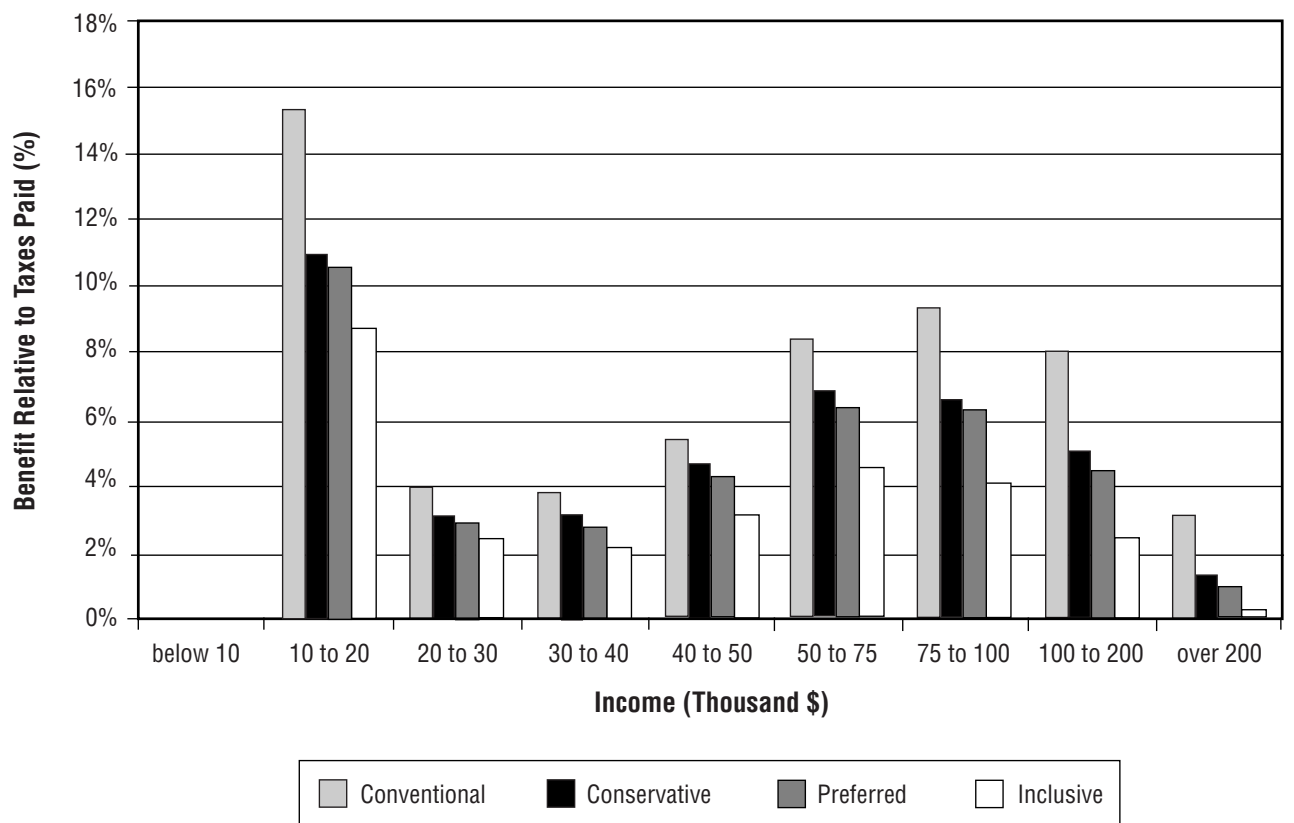

Source: Authors' calculations using US SCF 1998 data. 
Figure 5

Home Ownership and Mortgage Incidence by Age

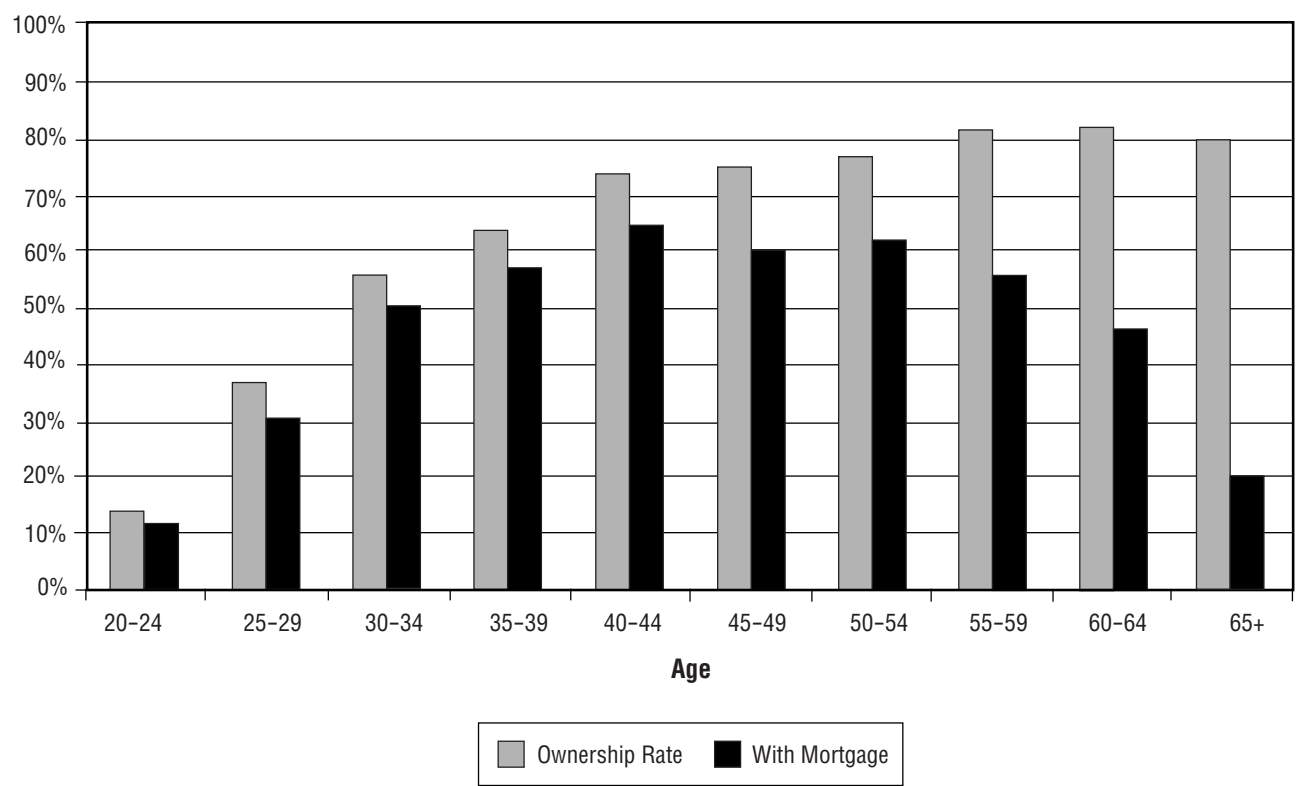

Source: Authors' calculations using US SCF 1998 data.

increases more or less at the same rate as the homeownership rate, this fraction declines steadily after age 40 to 44 . This seems to suggest that younger and potentially new homeowners rely more heavily on mortgage debt than their older counterparts. To examine the extent to which mortgage interest deductibility matters for new homeowners, Figure 6 depicts the benefits from mortgage interest deductibility for homeowners of different ages. This figure clearly shows that the conventional measure misses the importance of mortgage interest deductibility for new home buyers. By contrast, all three of our measures indicate that MID benefits increase as the homeownership rate increases and declines thereafter. Our measures thus suggest that new home buyers, who rely heavily on mortgage debt to finance their first house, care much more about mortgage interest deductibility than older homeowners, a pattern that does not emerge from the conventional measure.

\section{Evidence from Canadian Data}

As we alluded to earlier, mortgage interest payments are not deductible in Canada. Although there are many differences between the Canadian and the American tax systems, we can nevertheless use $\mathrm{Ca}$ nadian data to gain confidence in our measures of the cost and distributional effects of removing mortgage interest deductibility. ${ }^{26}$ We do so by using the 1999 Canadian Survey of Financial Securities (SFS), which contains data similar to that found in the SCF for the United States.

To begin, the home-ownership rate in Canada has been comparable to that of the US in recent years. For example, the home-ownership rate in Canada went from 63.6 percent in 1996 to 65.8 percent in 2001, while it increased from 65.4 percent to 67.8 percent during the same period in the US. ${ }^{27}$ The 


\section{FiguRE 6}

Distribution of Benefits of MID by Age for Homeowners

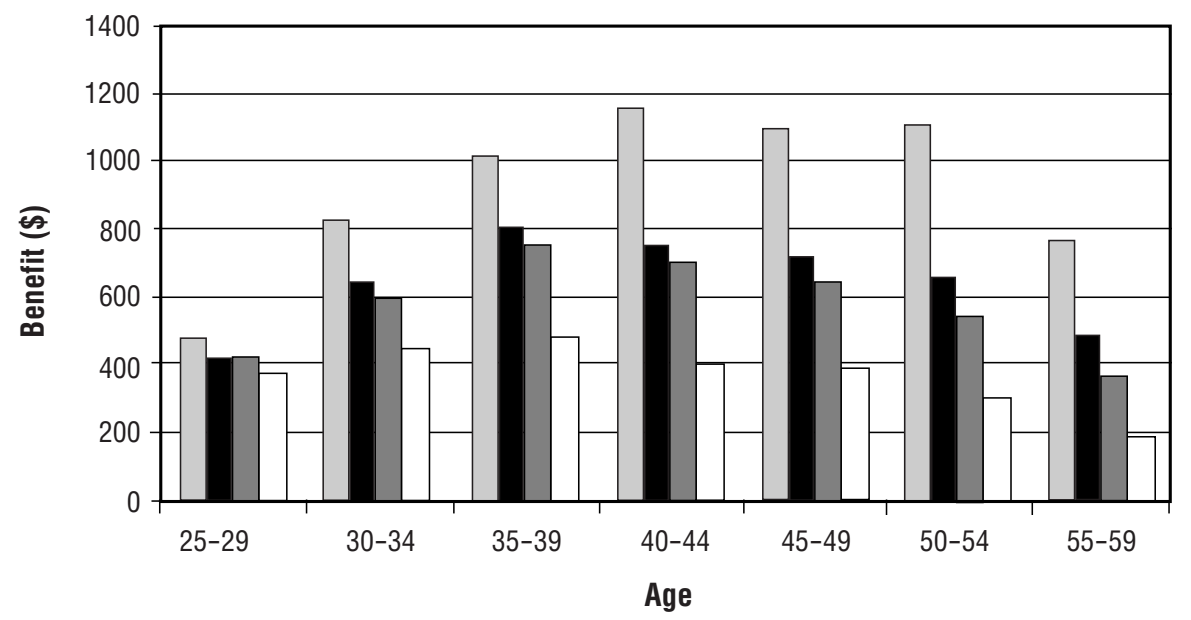

Conventional

Conservative

Preferred

Inclusive

Source: Authors' calculations using US SCF 1998 data.

home-ownership rate in the SFS, however, is only 60.4 percent. Meanwhile, the incidence of mortgage debt in the SFS is 32.7 percent, that is, a little over half (54.1 percent) of homeowners in the Survey have outstanding mortgage debts. In the SCF, where the home-ownership rate is 66.3 percent, the incidence of mortgage debt is 43.5 percent, that is, 65.6 percent of homeowners in the Survey have outstanding mortgage debt. Figure 7 depicts the Canadian home-ownership rate and mortgage incidence by income-the Canadian counterpart of Figure 1 for the US. ${ }^{28}$ Notice that while the home-ownership rate in Canada is much lower than in the US at low levels of income, they are very similar at higher levels of income. In contrast to the US, however, mortgage incidence displays a hump in Canada. This figure thus shows that high earners in Canada are much less likely to have outstanding mortgage debt than their US counterparts. ${ }^{29}$
Figure 8, according to our measures, depicts the fraction of households by income with outstanding mortgage debt that would result if mortgage interest deductibility were removed from the US tax code. The figure shows that for all three measures the fraction of households with mortgage debt peaks and then declines and looks remarkably similar to that obtained from Canadian data (Figure 7).

Table 5 provides further evidence that unlike homeowners in the US, Canadian homeowners tend to pay off their mortgage before accumulating nonresidential assets. For each age group, the numbers in this table represent the mean amount of nonresidential assets held by homeowners with a mortgage relative to the amount of non-residential assets held by homeowners without a mortgage. ${ }^{30}$ A value of one thus means that homeowners with and without mortgage debt tend to hold the same 


\section{FIGURE 7}

Home Ownership and Mortgage Incidence by Income for Canada

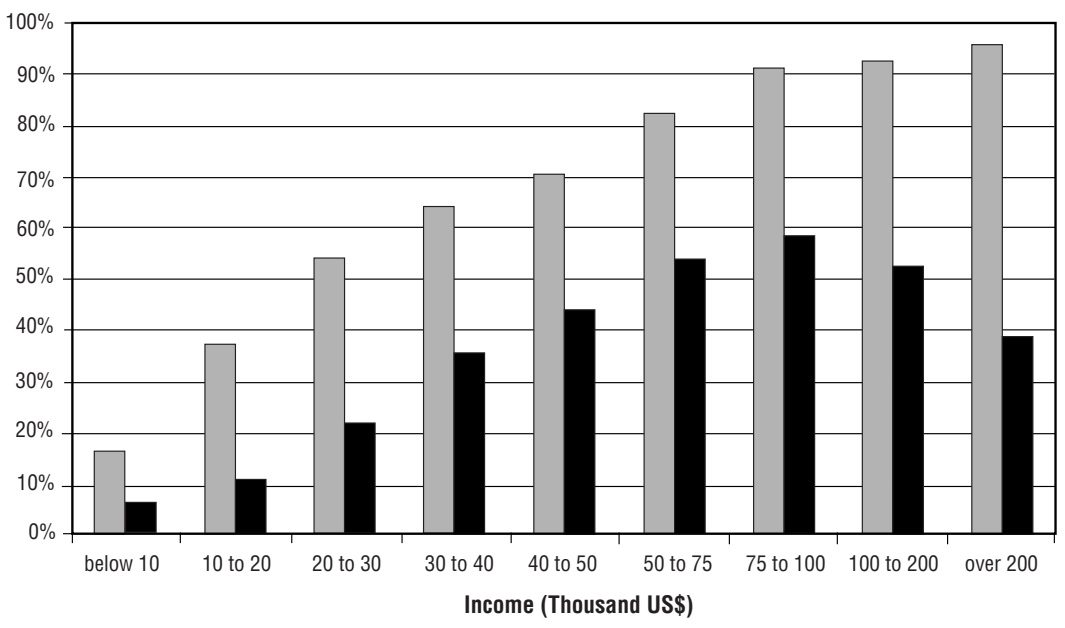

Ownership Rate

With Mortgage

Source: Authors' calculations using Canadian SFS 1999 data.

\section{FIGURE 8}

Mortgage Incidence by Income after Reshuffling

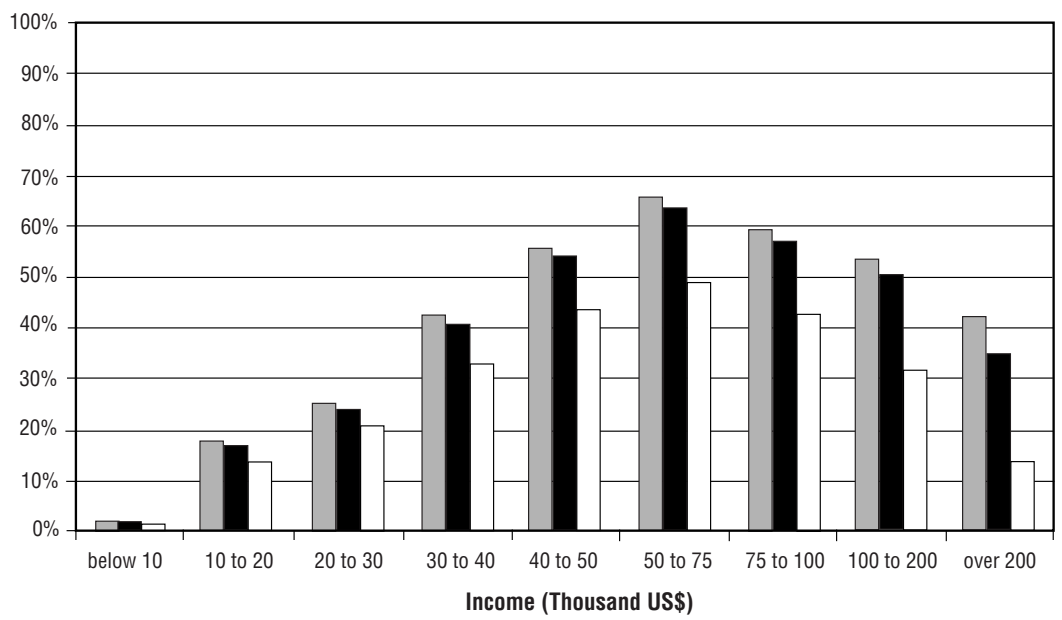

$\square$ Conservative $\square$ Preferred $\square$ Inclusive

Source: Authors' calculations using US SCF 1998 data. 
TABLE 5

Mean Non-Residential Assets for Homeowners with a Mortgage Relative to those Without

\begin{tabular}{lccccc}
\hline Age & Canada & US & Conservative & Preferred & Inclusive \\
\hline $25-29$ & 2.38 & 2.91 & 0.64 & 0.64 & 0.47 \\
$30-34$ & 1.46 & 1.73 & 0.73 & 0.70 & 0.58 \\
$35-39$ & 1.25 & 2.71 & 1.22 & 1.17 & 0.87 \\
$40-44$ & 0.82 & 3.95 & 0.66 & 0.64 & 0.49 \\
$45-49$ & 0.83 & 1.82 & 0.56 & 0.53 & 0.41 \\
$50-54$ & 0.69 & 2.03 & 0.66 & 0.61 & 0.52 \\
$55-59$ & 0.81 & 1.37 & 0.51 & 0.47 & 0.42 \\
$60-64$ & 0.80 & 1.18 & 0.32 & 0.30 & 0.26 \\
$65+$ & 0.82 & 1.94 & 0.68 & 0.63 & 0.59 \\
\hline
\end{tabular}

Source: Authors' compilation.

amount of non-residential assets. A value above one, as is the case for all age groups in the US, means that homeowners with a mortgage tend to own more nonresidential assets than those who own their house outright. Finally, a value below one, as is the case for Canadian households above 40 years of age, means that homeowners with 100 percent equity in their house tend to have more non-residential assets than homeowners with outstanding mortgage debt. The last three columns of Table 5 suggest that these ratios for US homeowners would become much closer to those of their Canadian counterparts should mortgage interest deductibility be removed from the US tax code.

\section{Conclusion}

This paper argues that the conventional way of measuring the cost, in terms of government revenue losses, of allowing mortgage interest deductibility is highly overstated in the literature. The reason is simple: households would reshuffle their balance sheet if mortgage interest deductibility were abolished. Since the conventional measure assumes that individual behaviour would not change after the elimination of tax expenditures, it greatly overstates the cost of this program.

We compute three alternative measures of the cost of mortgage interest deductibility. Each measure computes the amount of assets that households would use to buy out mortgage debt if MID were abolished. These measures differ as to the kind of assets households would use for this purpose. We find that the cost of MID is between 36 percent and 66 percent of the conventional measure.

We also characterize the distributional impact of MID. According to our preferred measure, the benefits of MID do not increase with wealth for wealth levels above the median. We also argue that while the benefits of MID increase with income, they do not increase as fast as taxes paid. Accordingly, we conclude that mortgage interest deductibility makes the tax code less progressive at relatively low levels of income and more progressive for relatively high levels of income. Finally, we show that mortgage interest deductibility is particularly important for new home buyers, a pattern that does not emerge under the conventional measure. 
The misconceptions that are at the heart of our analysis plagued Ontario's newspapers during the 2003 provincial election. Ernie Eves' proposal to phase in mortgage interest deductibility was perceived by the press as an expensive program that would provide a tremendous tax relief for the rich and not much for the middle-class. To quote an editorial from the Toronto Star: "A young family with a modest income and a 7 percent, $\$ 150,000$ mortgage, for example, would save about $\$ 465$ a year in taxes when the scheme was fully in place. But a millionaire, with a $\$ 1.5$ million mortgage on a monster home in one of Toronto's toniest neighbourhoods, would see his taxes go down by close to $\$ 6,000$ " (Toronto Star, 11 April 2003). Although our results suggest that such statements most likely overstate the cost and distributional effects this program would have in Canada, more precise estimates would have to take into account the fact that Canadians tend to save more in tax-sheltered form than do Americans (see Milligan 2005), which could mitigate the balance sheet reshuffling effect that we emphasize.

This type of analysis is, of course, subject to some caveats. Although the US Survey of Consumer Finances offers high-quality data on assets and liabilities, it contains virtually no information about their characteristics. In particular, we have no information on the return or the risk of any of the components of households' portfolio. In an attempt to circumvent this issue, we consider several measures of assets that households would use to lower their outstanding mortgage debt following the elimination of mortgage interest deductibility. However, this leaves open the possibility that households may use mortgage debt to diversify their portfolio (see Berkovec and Fullerton 1992). A second caveat is that our analysis does not allow us to make any normative statements with respect to this program. To do so would require a fully specified dynamic model of individual behaviour with an explicit tenure choice, which we leave for future research.

\section{Notes}

We would like to thank participants at the Bank of Canada Housing Conference and the Canadian Public Economics Study Group for helpful comments, as well as Ken McKenzie who discussed a previous version of the paper. We are grateful to Kevin Moore at the Federal Reserve Board who provided us with his code to compute taxes. Martin Gervais gratefully acknowledges financial support from the Social Sciences and Humanities Research Council of Canada. Manish Pandey gratefully acknowledges financial support from the Board of Regents, the University of Winnipeg.

${ }^{1}$ In the United States, mortgage interest deductibility allows taxpayers to deduct qualified interest paid on up to $\$ 1$ million in acquisition debt secured by the taxpayer's principal residence and one other residence. Taxpayers may also deduct interest on up to $\$ 100,000$ in home equity debt. The total of the acquisition and home equity debt on which the deduction is taken cannot exceed the fair market value of the home. See http://www.irs.gov/ publications/p936/ar02.htmI\#d0e175 for a detailed explanation of what qualifies as a mortgage interest deduction.

${ }^{2}$ For a detailed discussion of the issue refer to http:// www.pmabrethour.com/message/message23.html and http://www.theglobeandmail.com/series/election $2 \mathrm{k} 3$ / news/analysis $11 . h t m l$.

${ }^{3}$ Itemization refers to deduction from a taxpayer's taxable adjusted gross income that is made up of deductions for money spent on certain goods and services throughout the year. The specific deductions that are allowed are outlined by the IRS and include such expenses as mortgage interest, state and local taxes, gifts, and medical expenses. As an alternative to standard deduction, an itemized deduction requires taxpayers to keep track of each possible tax-reducing expense throughout the year.

${ }^{4}$ Skinner and Feenberg (1990) and Maki (1996, 2001) make a similar argument in a different context. Following the 1986 tax reform, which eliminated deductibility of interest paid on consumer debt, households reshuffled their balance sheet by increasing their mortgage debt to pay off their consumer debt.

${ }^{5}$ Similar results can be found in Hendershott, Pryce and White (2003), who study the change in loan-to-value 
ratio of housing purchases following the phasing out of MID in the United Kingdom.

${ }^{6}$ The income data contained in the SCF are sufficiently detailed to compute each household's tax liability using NBER's TaxSim model. See Feenberg and Coutts (1993) for information on the TaxSim model.

${ }^{7}$ We use the 1998 SCF because it is the most recent wave of the Survey which has some geographical information.

${ }^{8}$ Convincing evidence that such a reshuffling occurs when mortgage interest deductibility is removed can be found in Alan and Leth-Petersen (2006) who investigate the responsiveness of household portfolios to changes in the tax provision for Denmark.

${ }^{9}$ Given the nature of our analysis, another caveat of this paper is that no normative statements can be made based on changes in allocations; for example, changes in housing size, following the removal of mortgage interest deductibility.

${ }^{10}$ Indeed, Maki (2001) writes that because Congress "determined that encouraging home ownership is an important policy goal, achieved in part by providing a deduction for residential mortgage interest," it chose to retain the residential mortgage interest deduction (Joint Committee on Taxation 1987, 263-64) while it eliminated interest deduction on all other consumer loans.

${ }^{11}$ In fact, the Bush administration's 2002 budget stated that "the Administration believes the meaningfulness of tax expenditure estimates is uncertain" (Office of Management and Budget 2002) and promised a new more meaningful presentation in future years.

${ }^{12}$ Gervais (2002) argues that this tax advantage is far more important than mortgage interest deductibility to explain households' tenure decision. Ling and McGill (1993) argue that the failure to tax imputed rents involves much more revenue losses for the government than allowing mortgage interest deductibility.

${ }^{13}$ This is a conservative assumption, in the sense that assuming a (positive) wedge between the lending and borrowing interest rates would only serve to lower our measures of the cost of mortgage interest deductibility.

${ }^{14}$ See Appendix II for details on how we compute tax rates. See Feenberg and Coutts (1993) for details about the TaxSim model.
${ }^{15}$ The US tax code implies that a household should itemize its deductions if total itemized deductions are greater than the standard deduction allowed for the household. Standard deductions depend on the tax filing status of households. For the tax year 1997 standard deductions were as follows: Single household $\$ 4,150$; married filing jointly $\$ 6,900$; head of household $\$ 6,050$. We assume that all married households file taxes jointly.

${ }^{16}$ Without depreciation, imputed rents correspond to the value of housing services, so these terms cancel out for homeowners.

${ }^{17}$ We also omit timing issues that arise in cases such as capital gains, which are taxed only when realized.

${ }^{18}$ Unfortunately, the SCF does not report households' state of residence, which is important for US tax calculations in general, but especially crucial for mortgage interest deductibility calculations. To circumvent this problem, we use the 1998 version of the SCF, which is the most recent wave of the Survey for which households reported their census region. We use this information to compute tax liabilities and tax rates for each state in which a household could reside. We then use a population weighted average to get our estimates of each household's tax liability and tax rate. See Appendix I for details.

${ }^{19}$ The SCF is sufficiently detailed for us to compute outstanding mortgages for each household as the sum of the remaining mortgage on the principal residence and one other residence, as specified by the tax law (see note 1). For households with more than two residences, the second residence is the one with the highest mortgage interest payment.

${ }^{20}$ As emphasized in the Introduction, the IRS does have information on the revenue (flow data) generated by each component of taxpayers' balance sheet-each taxpayer needs to report $(i b) k$ and $(i a) k$, which could be used to implement our calculation through a flow approach.

${ }^{21}$ For practical purposes, the cost for each household $k$ is given by $C^{* k}=C^{k}+\Delta^{k}$, where $\Delta^{k}=\tau^{k} \times(i \times b)^{k}$ if $a^{k} \geq b^{k}$ or $\Delta^{k}=\tau^{k} \times i \times a^{k}$ if $a^{k}<b^{k}$. In other words, we use the household-specific mortgage interest rate as it is available in the SCF, but use the common interest rate $i$ for asset income as this interest rate is not available in the data. 
${ }^{22}$ Engen and Gale (1997) show that the rise in 401(k) assets among homeowners was associated with a rise in mortgage borrowing. Accordingly, they argue that the increase in mortgage credit could have emanated from the increased availability of tax-sheltered savings plans rather than the loss of interest deductibility on consumer loans.

23 This number is computed from the Canadian Survey of Financial Security.

${ }^{24}$ Benefits from mortgage interest deductibility across the wealth (net worth) distribution for our four measures show that for the conventional measure, benefits from MID increase exponentially with wealth. However, for our preferred measure benefits only increase in wealth for relatively poor households while for our inclusive measure the benefits are decreasing in wealth for households above median wealth.

25 Households with income between $\$ 10,000$ and $\$ 20,000$ are mainly retired individuals. For the working age population, households in this income range pay negative taxes on average, just like households with income below $\$ 10,000$, for whom we set the relative benefit to zero in Figure 4.

${ }^{26}$ It is important to note that there are, of course, many other differences between the Canadian and US tax treatment of income from various assets, which also affect the portfolio decisions of Canadian and American households. Of particular interest is the fact that the fraction of wealth held by Canadians in tax-differed assets is much larger than that of US households. See Milligan (2005) and Poterba and Samwick (2002) for details on Canadian and American household asset allocations, respectively.

${ }^{27}$ Home-ownership rates for Canada are from Census data.

${ }^{28}$ We use the real exchange rate from Penn World Table 6.1 to convert income and wealth from the SFS into US dollars, and the CPI to deflate them back to 1997.

${ }^{29}$ This hump-shaped pattern of mortgage incidence in Canada (not shown) is even more pronounced with respect to wealth.

${ }^{30}$ For each household, non-residential asset holdings are defined as total assets minus the value of their principal residence, the value of their vehicles, and the value of retirement assets. This definition thus corresponds to our definition of interest-bearing assets for the inclusive measure introduced in the third section.

\section{ReferenCeS}

Alan, S. and S. Leth-Petersen. 2006. "Tax Incentives and Household Portfolios: A Panel Data Analysis.” Unpublished manuscript.

Berkovec, J. and D. Fullerton. 1992. "A General Equilibrium Model of Housing, Taxes, and Portfolio Choice." Journal of Political Economy 100(2):390-429.

Bourassa, S.C. and W.G. Grigsby. 2000. "Income Tax Concessions for Owner-Occupied Housing." Housing Policy Debate 11(3):521-46.

Budría Rodríguez, S., J. Díaz-Giménez, V. Quadrini and J.-V. Ríos-Rull. 2002. "Updated Facts on the U.S. Distributions of Earnings, Income, and Wealth." Federal Reserve Bank of Minneapolis Quarterly Review 26(3):2-35.

Dunsky, R. and J.R. Follain. 2000. "Tax-Induced Portfolio Reshuffling: The Case of the Mortgage Interest Deductibility." Real Estate Economics 28(4):683-718.

Engen, E.M. and W.G. Gale. 1997. "Tax-Preferred Assets and Debt and the Tax Reform Act of 1986: Some Implications for Fundamental Tax Reform." National Tax Journal 49(3):331-39.

Feenberg, D. and E. Coutts. 1993. "An Introduction to the TaxSim Model." Journal of Policy Analysis and Management 12(1):189-94.

Follain, J.R. and R. Dunsky. 1997. "The Demand for Mortgage Debt and the Income Tax." Journal of Housing Research 8(2):155-99.

Follain, J.R. and L.S. Melamed. 1998. "The False Messiah of Tax Policy: What Elimination of the Home Mortgage Interest Deduction Promises and a Careful Look at What it Delivers." Journal of Housing Research 9(2):179-99.

Gervais, M. 2002. "Housing Taxation and Capital Accumulation." Journal of Monetary Economics 49(7):1461-89.

Glaeser, E.L. and J.M. Shapiro. 2003. The Benefits of the Home Mortgage Interest Deduction." Tax Policy and the Economy 17:37-82.

Hendershott, P.H., G. Pryce and M. White. 2003. "Household Leverage and the Deductibility of Home Mortgage Interest: Evidence from U.K. House Purchases." Journal of Housing Research 14(1):49-82. 
Joint Committee on Taxation. 1987. General Explanation of the Tax Reform Act of 1986. Washington, DC: US Government Printing Office.

Kennickell, A.B., M. Starr-McCluer and B.J. Surette. 2000. "Recent Changes in U.S. Family Finances: Results from the 1998 Survey of Consumer Finances." Federal Reserve Bulletin 86(January):1-29.

Ling, D.C. and G.A. McGill. 1993. "Measuring the Size and Distributional Effects of Homeowner Tax Preferences." Journal of Housing Research 3(2):273-303.

Maki, D.M. 1996. Portfolio Shuffling and Tax Reform." National Tax Journal 49(3):317-29.

- 2001. "Household Debt and the Tax Reform Act of 1986." American Economic Review 91(1):305-19.

Milligan, K. 2005. "Life-Cycle Asset Accumulation and Allocation in Canada." Canadian Journal of Economics 38(3):1057-106.

Poterba, J.M. 1990. “Taxation and Housing Markets: Pre- liminary Evidence on the Effects of the Recent Tax Reform." Do Taxes Matter? The Impact of the Tax Reform Act of 1986, ed. J. Slemrod. Cambridge, MA: MIT Press.

Poterba, J.M. and A.A. Samwick. 2002. "Taxation and Household Portfolio Composition: US Evidence from the 1980s and 1990s." Journal of Public Economics 87(1):5-38

Skinner, J. and D. Feenberg. 1990. "The Impact of the 1986 Tax Reform on Personal Saving." Do Taxes Matter? The Impact of the Tax Reform Act of 1986, ed. J. Slemrod. Cambridge, MA: MIT Press.

United States. Office of Management and Budget. 2002. Budget of the United States Government, Fiscal Year 2002. Washington, DC: US Government Printing Office. - 2005. Analytical Perspectives, Budget of the United States Government. Washington, DC: US Government Printing Office. 


\section{APPENDIX I \\ SCF Data and Definition of Wealth}

The data for household wealth and income used in this paper are from the 1998 Survey of Consumer Finances (SCF). The SCF is a triennial survey of households sponsored by the Federal Reserve Board. The survey collects information on assets, liabilities, income, employment, demographics and relationship with financial institutions, and contains information for 4,305 households. ${ }^{1}$

Information on the state of residence of households is crucial for tax computations since income tax rates differ across states and state income taxes are deductible at the federal level. For confidentiality reasons, unfortunately, the state of residence is not available in the public dataset. However, the 1998 SCF dataset provides the census region of residence of the household. Census regions are based on a geographic division of the country into nine regions with each census region consisting of between three and nine states. Using the census regions we overcome the lack of information about the state of residence by computing income taxes for a household in a region for each of the states in the region and then taking a population weighted average over the states to get the tax liability of the household.

The definition of wealth used in this paper corresponds to net worth, defined as the difference between assets and liabilities for a household. The wealth concept used is referred to as marketable wealth and is the same as that used by Kennickell, Starr-McCluer and Surette (2000) and Budría Rodríguez et al. (2002). ${ }^{2}$

\section{Assets}

\section{Financial Assets}

1. Liquid assets: checking accounts, savings accounts, money market mutual funds and call accounts with brokers

2. CDS: certificates of deposit

3. Taxable NMMF: taxable non-money market mutual funds

4. Tax-exempt NMMF: non-taxable non-money market mutual funds

5. Stocks

6. Taxable bonds

7. Tax-exempt bonds

8. Retirement assets: IRAs, thrift-type accounts and future pensions and includes tax-deferred equity and tax-deferred bonds

9. Other financial assets: cash value of whole life insurance, other managed assets (trusts, annuities, and managed investment accounts) and loans, future proceeds, royalties, futures, non-public stock, deferred compensation, oil/gas/mineral invest., cash n.e.c.

\footnotetext{
${ }^{1}$ As suggested by the SCF 1998 code book, a weighted average of the "implicates" is used for the computations that follow with the weight associated with each implicate divided by five. See the code book for the 1998 SCF for details.

${ }^{2}$ The code we use for wealth computation is available at http://www.federalreserve.gov/pubs/oss/oss2/95/ codebk95pt5.html.
} 


\section{Non-Financial Assets}

1. Vehicles: autos, motor homes, RVs, airplanes, boats

2. House(s): primary and secondary residence

3. Other residential real estate

4. Business (net worth): value of net equity if business were sold today

5. Net equity in non-residential real estate

6. Other (net) non-financial assets

\section{Debt}

\section{Mortgage Debt}

1. Mortgage debt: mortgage, home equity loans and HELOCs on primary and secondary residence

\section{Other Debt}

1. Other lines of credit

2. Loans: credit card debt and installment loans

3. Other debt: loans for pensions, loans for life insurance, margin loans, miscellaneous 


\section{APPENDIX II \\ TAX COMPUTATION}

TaxSim version 5.1 provided by the NBER is used to compute income taxes for each household in the SCF dataset for the 1997 tax year. ${ }^{3}$ Income taxes are computed under the following assumptions: (a) the filing unit is the household; (b) all cohabitating and married couples file jointly; and (c) itemization status is determined by TaxSim and not by a direct question in the SCF. A household from a census region is given states codes for all states in the region. This provides between three and nine different sets of data for each household depending on the region of residence. The data are then uploaded to TaxSim to compute the adjusted gross income (AGI), tax liability, and marginal tax rate for each household in the dataset and for each state of the region of residence. Doing so, we compute tax liabilities and marginal tax rates for each state in which the household may reside. Each household's tax liability and marginal tax rate are then computed as the weighted average over all states in the region, where the weights are taken to be population weights from census data.

\footnotetext{
${ }^{3}$ The code to compute the information required by TaxSim from SCF data was provided by Kevin Moore from the Federal Reserve Board.
} 